論 文・Paper

\title{
ハロイサイト鉱物の層間水の脱水機構
}

\author{
岡田 清 - 小坂丈予 \\ (東京工業大学 工学部 無機材料工学科)
}

\begin{abstract}
室温において相対湿度条件を変化させた際のハロイサイト鉱物の層間水の脱水機構について重量 変化の測定と粉末X線回折法を用いて検討した. 相対湿度を 60 ～10\% まで変えた雰囲気中での層 間水の脱水反応がほぼ平衡状態に達するのには 3 5 日程度の時間を必要とする. 脱水の際の構造 変化について非干渉モデルと干渉モデルの両方を検討した．その結果，(00l) の高次の回折線の出 現位置から非干渉モデルは脱水モデルとして不適当であると結論された．これに対して，干渉モデ ルについて強度比較法により検討した結果, ハロイサイト $10 \AA$ の層と脱水相のハロイサイト $7 \AA$ の層とは脱水により 2 相分離の関係になっていることが判明した.この結果を少し理想化して考え ると, 脱水反応は一つの結晶子の外側から内部へと層に垂直な方向に優先的に脱水が進行するとい うモデルが考えられた.このモデルから予想される反応速度式はゼロ次反応であるが，実際には結 晶子が多数集合して形成される 数千 $\AA$ 程度の大きさの球状粒子内部からの拡散等の影響を強く受 けているため, 見掛け上ゼ口次反応に従わない結果をもたらしたものと考えられた.
\end{abstract}

(1982 年 12 月 6 日受付)

\section{Dehydration Mechanism of Interlayer Water of Halloysite}

\author{
Kiyoshi OKADA and Joyo OSSAKA \\ $\left(\begin{array}{l}\text { Department of Inorganic Materials, Tokyo Institute of Technology } \\ \text { 12-1, Ookayama 2-chome, Meguro-ku, Tokyo } 152\end{array}\right)$
}

\begin{abstract}
Dehydration mechanism : of interlayer water of halloysite (10 $)$ under various relative humidity conditions at room temperature was investigated by weight loss and powder X-ray diffraction analysis. It was found that the dehydration reactions under relative humidities of $60 \sim 10 \%$ need 3 5 days for attaining an equilibrium state. Both the incoherent and coherent models for dehydration were examined using the correlation method. The incoherent model was concluded to be inadequate because the spacings of $(00 \mathrm{l})$ reflections were not rational. The coherent model in which the layers of halloysite $(10 \AA)$ and halloysite $(7 \AA)$ segregated each other, was concluded to be most plausible. The idealized model in which dehydration progressed preferably perpendicular to the layers of each crystallite is proposed. The reaction was expected to obey zero order law from this model. It was considered, however, that the zero order law was not obeyed because of the diffusion from the inner part of the spheroidal particles, which were formed by gathering many crystallites and were several thousands angstroms in diameter. [Received December 6, 1982]
\end{abstract}

Key-words : Halloysite, Dehydration mechanism of interlayer water, Interstratified structure, Order of dehydration reaction

\section{1. 緒言}

ハロイサイトはカオリン鉱物に属する鉱物であるが, 層間水を有する点で他のカオリン鈗物と異なっている. この層間水は一般的には比較的脱水しやすく，大気中で
さえ徐々にではあるが脱水して底面間隔がハロイサイト $10 \AA$ 相の $10 \AA$ からハロイサイト $7 \AA$ 相の $7 \AA$ へと非 可逆的に変化することもあるのに対して, この逆の反応 は特殊な薬品処理1)を行わないかぎりほとんど進行しな 
いことが知られている．従来，八ロイサイトが比較的容 易に層間水を失うこの現象については多くの報告 ${ }^{22 \sim 4)}$ が あり, Nagasawa ら (4) 層間水の安定性とハロイサイト の生成年代との関係について検討し，一般的には生成年 代が古く, 結晶性の良い試料のほうが層間水が不安定で あることを報告している.このほか，水熱条件下での脱 水挙動についても Churchman $ら^{5)}$ と Minato ら ${ }^{6)}$ の報 告があり，それによると $120^{\circ} \mathrm{C}$ 以上の高温下では八ロイ サイト $10 \AA$ の層間水は不安定で脱水相の八ロイサイト $7 \AA$ に変化することが報告されている.

一方, 層間水の脱水に伴う構造変化, 反応機構等に関 する報告は少ない. Brindley ら ${ }^{2)}$ はこの脱水様式につ いて検討し，ハロイサイト $10 \AA$ は $2 \mathrm{SiO}_{2} \cdot \mathrm{Al}_{2} \mathrm{O}_{3} \cdot n \mathrm{H}_{2} \mathrm{O}$ の化学式で表すと $n$ が 3.5 4 に，一方ハロイサイト $7 \AA$ は $n$ が 2.33〜2.67 の状態にそれぞれ対応してお り，この中間の状態は両者の混合した状態でX線的には 非干涉の状態であると考えた.これに対してChurchman $ら^{57}$ はこの脱水過程に扔ける $2 \theta$ が $9 \sim 12^{\circ}$ 付近の回折 線の変化を $10.1 \AA$ と $7.2 \AA$ の底面間隔の 2 相が $\mathrm{X}$ 線 的に干渉状態にあり混合層構造を形成していると考え， MacEwan ら ${ }^{8}$ の式を用いてこれを解析し，2相が “partial segregation” の関係にあると報告している。こ れら二つの脱水モデルは 2 相が相分離の状態で脱水する と考えている点では類似しているが, ハロイサイト $10 \AA$ と八ロイサイト $7 \AA$ とが $\mathrm{X}$ 線的に干渉状態であるか否 かについては異なっている.

そこで, 本研究では八ロイサイトの脱水の際両相が X 線的に干涉状態にあるか否かについて (001)*の回折線 だけでなく高次の回折線の挙動についても検討し，干渉 モデルの強度の計算には Kakinoki ら ${ }^{122}$ の式を用いて (00 ほ)のX線プロファイルを算出し, 強度比較法により 層間水の脱水様式について詳細に検討したので，その結 果について報告する.

\section{2. 実 験 方 法}

実験に用いた試料は長野県伊那産のハロイサイトで， 約 8 万年前に降下, 堆積した御岳火山起源の軽石 ${ }^{13)}$ が地 表付近の風化作用を受け生成したと考えられるものであ る. 試料は現地の露頭で表層部分を十分はく離し, 新鮮 な部分より採取した. 試料は採取後も乾燥させないよう に十分留意し，そのまま沈降法を用いて水箕し， $2 \mu \mathrm{m}$ 以下の粘土部分を分離した. 得られた $2 \mu \mathrm{m}$ 以下の試料 を粉末 X線回折, DTA, 電子顕微鏡観察, 化学分析等に より検討した結果，含まれている粘土鉱物はほとんど八 ロイサイト $10 \AA$ 相のみで, このほかにはわずかにアロ

* 八ロイサイトが 2 層構造を有することは既に Honjo ら ${ }^{9)}$, Chukhrov ら ${ }^{10)}$ 及び神山ら ${ }^{11}$ により十分確立されているが， ここでは従来の慣例に従って $10 \AA$ の面間隔の回折線を (001) と指数付けして用いることにする.
フェンが混入していることが示唆されただけであった。

相対湿度は各種濃度の硫酸水溶液を用いて $20^{\circ} \mathrm{C}$ で $60 \%, 50 \%, 40 \%, 30 \%, 20 \%$ 及び 10\% の状態になる よう設定した. 試料はこれらの各相対湿度条件に設定し たデシケータ中に保持し, 所定時間ごとにそれらの重量 変化量を測定した.

粉末 $\mathrm{X}$ 線回折には理学電機社製のX線回折装 置を用 い，X線源としては試料中にわずかに含まれている酸化 鉄による蛍光 $\mathrm{X}$ 線の影響等を除去するためグラファイ ト・モノクロメーターで単色化した $\mathrm{Cu} K \alpha$ 線を使用し た. 測定は $2 \theta$ が $5^{\circ}$ から $30^{\circ}$ の範囲を $0.5^{\circ} / \mathrm{min}$ の走 查速度で行った. この測定では低角度域でX線ビームが 試料部をはずれないようにするために，0.5-0.6 mm$0.5^{\circ}$ のスリット系を用い, 更に被照射面積の広い試料 ホルダーとを組み合わせて用いた. この測定条件により $2 \theta$ が $6^{\circ}$ までの低角度域まで定量的な測定が可能であ った.

\section{1 測 定 結 果}

\section{3. 結果と考察}

相対湿度が 60〜10\% の雾囲気中に試料を保持したと きの重量減少量の時間依存性を図 1 に示した. 図 1 より 反応はほぼ 3〜5 日程度でほとんど完了することが判明 した. そこで約 1 か月間それぞれの条件下に保持した試 料について粉末 X線回折を行った. その結果を図 2 に示 したが，相対湿度が $60 \%$ から $10 \%$ へと低下するのに 対して, $2 \theta$ が $9^{\circ}$ 付近のハロイサイト $10 \AA$ の (001) 回折線の強度は減少し, 一方 $2 \theta$ が $12^{\circ}$ 付近の八ロイ サイト $7 \AA$ の (001) に相当する回折線の強度は逆に増 加する傾向を示す. また $2 \theta$ が $25^{\circ}$ から $27^{\circ}$ 付近でむ ハロイサイト $10 \AA$ の (003) に対応する $26.7^{\circ}$ 付近の 回折線強度の減少とハロイサイト $7 \AA$ の(002) に対応 する $24.6^{\circ}$ 付近のそれが増加するのが観察された. な お, $2 \theta$ が $20^{\circ}$ 付近の非対称な回折線は (02-) に対応 する $h k$ バンドであり，これは層間水の脱水による影響

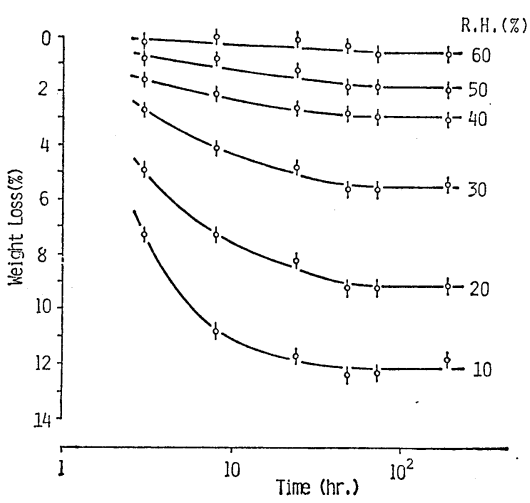

Fig. 1. Weight loss curves of halloysite under various relative humidity conditions. 


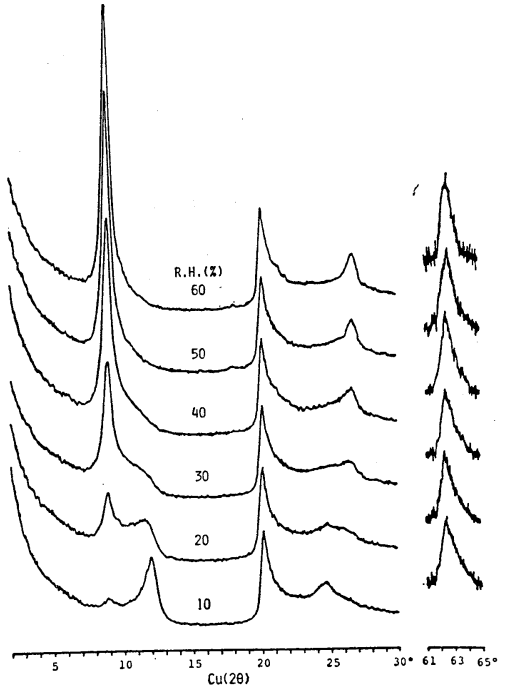

Fig. 2. The X-ray powder diffraction patterns of halloysite under various relative humidity conditions.

をほとんど受けない。しかし $2 \theta$ が $63^{\circ}$ 付近に出現す る(06-) の回折線の回折角度を詳細に検討すると, 相対 湿度が低くなるに従いわずかずっでは嵓るが回折線が低 角側に移動するのが認められた。

\section{2 非干渉モデル}

Brindley ら ${ }^{2)}$ はハロイサイトの層間水の脱水の際に ハロイサイト $10 \AA$ と脱水相の八ロイサイト $7 \AA$ とが $\mathrm{X}$ 線的には非干渉な関係にあり，図 2 に示したような $2 \theta$ が $9 \sim 12^{\circ}$ 付近の回折線は二つにピーク分離が可能 であり，ハロイサイト $10 \AA$ の（001）の面間隔は 9.5 〜 $10.1 \AA$ の值を，一方八ロイサイト $7 \AA$ のそれは 7.5 〜 7.9 ̊ の範囲の值をとると報告している. そこで本研 究でも図 2 の $2 \theta$ が $9 \sim 12^{\circ}$ 付近の回折線についてガウ

(A)

(B)

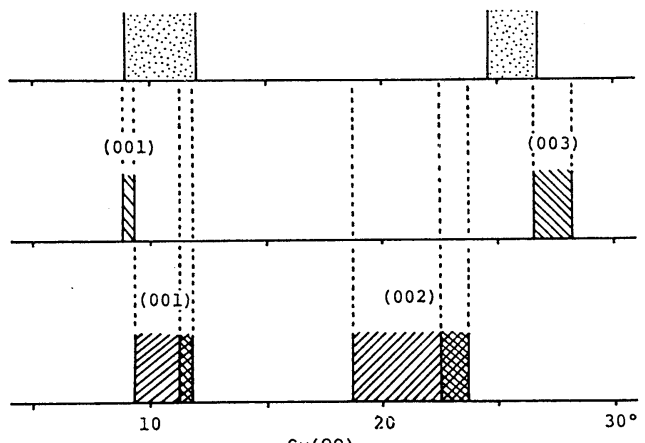

$\operatorname{Cu}(2 \theta)$

Fig. 3. The positions of the $(00 l)$ reflections of halloysite. (A) : Observed range, (B) : Calculated range of halloysite $10 \AA$ based on $d_{001}=$ 10.1 9.5 $\AA$, and (C) : That of halloysite $7 \AA$ based on $d_{001}=9.5 \sim 7.5 \AA$ (a slant lined range) and $d_{001}=7.9 \sim 7.5 \AA$ (doubly slant lined range).
ス関数及びローレンツ関数を用いて最小二乗法により二 つのピークに分離した. その結果，八ロイサイト $10 \AA$ の (001) の面間隔の值は 9.5 10.1 に に, 一方八ロイ サイト. $7 \AA$ のそれでは 7.5 9.5 の值が得られた. これらの值に対応する高次の回折線, つまりハロイサイ 卜 $10 \AA$ の (003) と八ロイサイト $7 \AA$ の (002) の出 現位置を(001) 回折線をピーク分離した結果を用いて算 出すると，それらは図 3 に示した範囲に相当する。つま り，観測された角度範囲は $2 \theta$ が $24.6 \sim 26.7^{\circ}$ の值 で あったのに対して，9.5 10.1 の 面間隔に対応する (003) の回折角は $26.5 \sim 28.2^{\circ}$ に, 一方 7.5 9.5 ̊ の 面間隔に対してその (002) の回折角は 18.7 23.7 対応し，、ずれも観測データの出現範团と異なる。ま た，Brindley ら2)の結果を用いても同様に観測データと 異なる.これらの結果より，この非干渉モデルはハロイ サイトの層間水の脱水モデルとしては適当ではないと結 論された.

\section{3 干渉モデル}

次に Churchman ららう提唱した干渉モデルについて

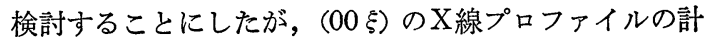
算には彼らの用いている MacEwan ら ${ }^{8)}$ の式よりも一般 性のある Kakinoki ら ${ }^{122}$ の式を用いた。それによると， 1 次元不整を示す結晶によるX線強度は一般的には次式 で表される.

$$
\begin{aligned}
I_{(00 \xi)}= & N \operatorname{spur} \boldsymbol{V} \boldsymbol{F}+\sum_{m=1}^{N-1}(N-m) \operatorname{spur} \boldsymbol{V} \boldsymbol{F} \boldsymbol{Q}^{m} \\
& + \text { conj. }
\end{aligned}
$$

ここで $N$ は層の枚数であり，また $\boldsymbol{V}$ は層構造因子， $\boldsymbol{F}$ は存在確率, $\boldsymbol{Q}$ は $\boldsymbol{Q}=\boldsymbol{\phi} \cdot \boldsymbol{P}$ で $\boldsymbol{\phi}$ は位相, $\boldsymbol{P}$ はつな がりの確率を表す行列にそれぞれ対応する. 本研究の場 合にはハロイサイト $10 \AA$ と八ロイサイト $7 \AA$ との混 合層構造を考えているので，それらの構造因子を算出す るための $z$ 座標の パラメーターとしては Hendricks ${ }^{14)}$ の值を用いた。 また層の枚数は粉末 $\mathrm{X}$ 線回折図形の $(00 l)$ の回折線の広がりから 10 20 枚程度と考えられ たが，このように層の枚数が少ない場合には低角度域の 計算図形が不安定になるので, この図形を安定化させる ために佐藤 ${ }^{(5)}$ の報告のように層の枚数に統計的分布を与 える方法で計算を行った. 計算には今回新しく作製した 計算プログラムを使用し, 東京工業大学計算機センター の $\mathrm{M}-200 \mathrm{H}$ 大型電子計算機を利用して，層の枚数，八 ロイサイト $10 \AA ̊$ の存在確率 $\left(W_{\mathrm{H}}\right)$, ハロイサイト $10 \AA$ 同士のつながりの確率 $\left(P_{\mathrm{HH}}\right)$ をそれぞれ変数として適 宜変化させ (2). 式に示した $R$ 值が最小となる条件を求 めた.

$$
R=\sum_{n=1}^{k}\left|I_{\mathrm{obs}}(n)-I_{\mathrm{cal}}(n)\right| / \sum_{n=1}^{k} I_{\mathrm{obs}}(n)
$$

ここで $I_{\mathrm{obs}}(n)$ と $I_{\mathrm{cal}}(n)$ は $2 \theta$ が $5 \sim 30^{\circ}$ の範囲を 
$0.2^{\circ}$ 間隔に区分したそれぞれの $2 \theta$ 值に対応するX線 強度の観測值と計算值である．図4にははそれぞれの観測 及び計算プロファイルを示したが，得られた $R$ 值はい ずれもほぼ 0.2 程度であり，観測プロファイルと良い一 致が得られた. 相対湿度 60〜10\% のそれぞれのプロフ

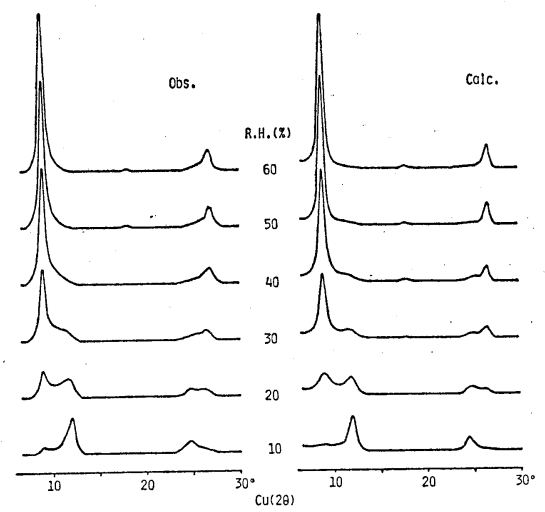

Fig. 4. The observed and calculated intensities of $(00 \xi)$ of halloysite.

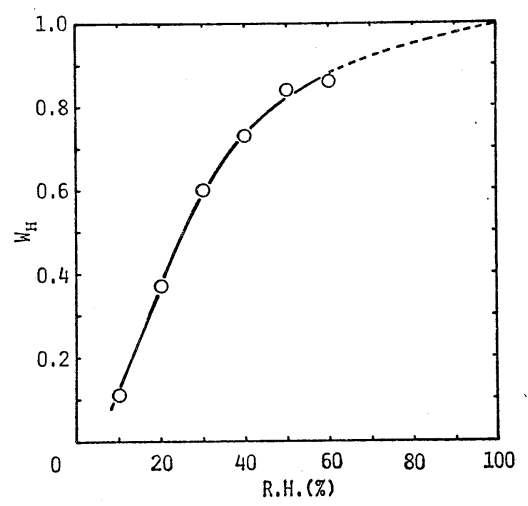

Fig. 5. The relation between the existence probability of halloysite $10 \AA\left(W_{\mathrm{H}}\right)$ and relative humidity (R.H.).

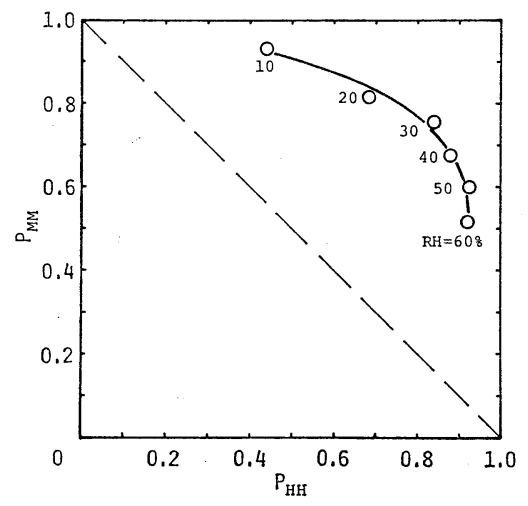

Fig. 6. The relation between the continuing probability of halloysite $10 \AA\left(P_{\mathrm{HH}}\right)$ and that of halloysite $7 \AA\left(P_{\mathrm{MM}}\right)$ under various relative humidity conditions.

アイルについて求められた層の枚数はいずれも 10 16 枚前後の值であった. また $W_{\mathrm{H}}$ と相対湿度との関係に ついては図5に示した。これよりハロイサイト $10 \AA ̊ 丿$ 存在確率は相対湿度の低下とともに減少し, 相対湿度が 約 $30 \%$ 弱の条件で脱水相が全体の半数を占める関係に あることが分る. 次に Sato' ${ }^{16)}$ の図を用いて $P_{\mathrm{HH}}$ と $P_{\mathrm{MM}}$ (ハロイサイト $7 \AA$ 同士のつながりの確率) の関 係を示したのが図 6 である。この図では $P_{\mathrm{HH}}=0, P_{\mathrm{MM}}$ $=1$ と $P_{\mathrm{HH}}=1, P_{\mathrm{MM}}=0$ とを結ぶ破線で示した直線上 がH層とM層とがランダムな関係にあることを意味して おり，この場合 $W_{\mathrm{H}}=P_{\mathrm{HH}}, W_{\mathrm{M}}=P_{\mathrm{MM}}$ の関係が成立 する.この破線より左下の領域は両層が order-disorder の関係で, $P_{\mathrm{HH}}=P_{\mathrm{MM}}=0$ の点は order な状態で $\mathrm{HMHMH}$ ‥という積層関係に対応する.これに対して, それより右上の領域は両層が segregate な関係で, $P_{\mathrm{HH}}$ $=P_{\mathrm{MM}}=1$ の点は逆に $P_{\mathrm{HM}}=P_{\mathrm{MH}}=0$ であり完全に 2 相が segregate した状態 HH…HHMM‥MM を意味し ている.なお，これらの両領域では（3）式が成立するの で, $W_{\mathrm{H}}$ と $P_{\mathrm{HH}}$ が決まると $P_{\mathrm{MM}}$ は一義的に決定さ れる。

$$
P_{\mathrm{MM}}=\left(W_{\mathrm{H}} P_{\mathrm{HH}}+W_{\mathrm{M}}-W_{\mathrm{H}}\right) / W_{\mathrm{M}}
$$

本研究で求められたそれぞれの $P_{\mathrm{HH}}, P_{\mathrm{MM}}$ の值は明ら かに segregationの領域を占めており，また相対湿度が 低下するのに伴って $P_{\mathrm{HH}}$ の確率が減少し, $P_{\mathrm{MM}}$ が増 加する関係にあることが判明した.

\section{4 考察}

ハロイサイトの層間水の脱水の際にもとの相と脱水相 とがX線的に干渉した状態を保ったまま反応するのかそ れとも非干渉な関係に変化するかについて検討した結 果, 両相が干渉状態を保ったまま脱水することが判明し た. そこで図 6 に示したような $P_{\mathrm{HH}}$ と $P_{\mathrm{MM}}$ のパラメ

(A)

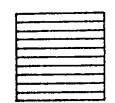

(B)
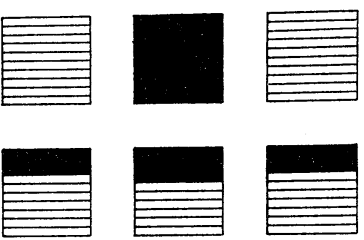

(C)

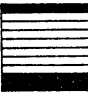

(D)
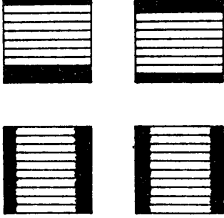

(E)
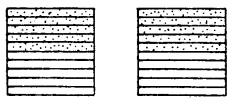

Fig. 7. Schematically depicted dehydration models.
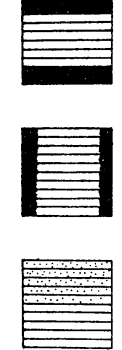
ーター変化が持つ意味をもう少し具体的に考察すること にする.

まず単純化した種々の脱水モデルを考え，それらの模 式化した図を図 7 に示した。 ここで図中の一つのブロッ クを結晶子と考えると，モデル（A）はその結晶子によ り脱水の状態が異なり，一つの結晶子で脱水反応が始ま るとその中ではすみやかに脱水反応が終了してしまう が，そのほかの結晶子ではそのままの状態で残存してい るものも存在するというように不均一な脱水反応を想定 したモデルである.（B）はこれに対して層に垂直な方 向に結晶子の外側から内部へとしかも一方向から優先的 に脱水反応が進行することを考虑したモデルであり，ま た（C）は（B）を更に一般化したモデルで脱水反応が結 晶子の両側から内部へと同時に進行すると考えたモデル である。また（D） は結晶子の側面から内部へと脱水が 進行すると考えたモデルであり，一方（E）は一つの層 間で一部が脱水すると考えたモデルである.これらの五 つのモデルのうち，(A) は八ロイサイト $10 \AA$ と八ロイ サイト $7 \AA$ とがX線的に非干渉な状態であることを意 味しており，一方（E）のモデルはハロイト $10 \AA ̊$ と八 ロイサイト $7 \AA$ の両相の中間的な状態の存在を考慮し ているもので，いずれも前述した観測結果と調和的なモ デルではない．また（D) のモデルは $W_{\mathrm{H}}$ の值にかか わらず $P_{\mathrm{HH}}=P_{\mathrm{MM}}=1$ に対応するので, 図 6 に示した 観測 $P_{\mathrm{HH}}, P_{\mathrm{MM}}$ のパラメーター変化とは明らかに異な る. そこで残った二つのモデルについて更に詳細に検討 するため, 層の枚数を $N=10 \sim 16$ とし, $W_{\mathrm{H}}$ を変化さ せた場合の $P_{\mathrm{HH}}, P_{\mathrm{MM}}$ の值を算出し, 図 8 に示した. 図中の白丸印が観測データより求められた值であり，一 方斜線付けした領域がそれぞれ（B）と（C）のモデルよ り算出される $P_{\mathrm{HH}}$ と $P_{\mathrm{MM}}$ の存在範囲を示したもので ある.ただし，これらの領域は層の枚数が多くなると全 体に右上方向へ, 一方層の枚数が少なくなると逆に左下 方向へとシフトするので, それ ぞれ (B) と (C) の領

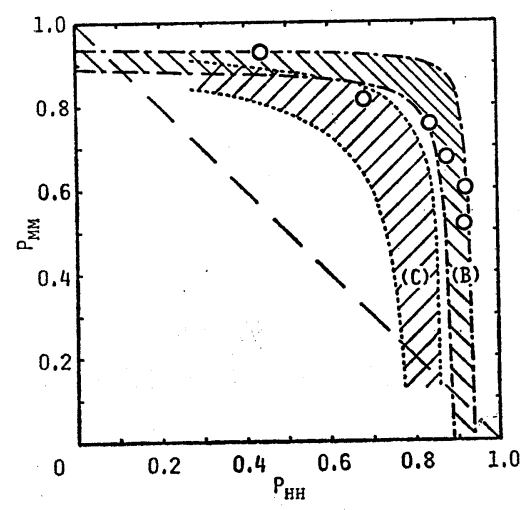

Fig. 8. The ranges of $P_{\mathrm{HH}}$ and $P_{\mathrm{MM}}$ calculated with models $(B)$ and $(C)$. Open circles represented the observed values.
域の左側の境界線が $N=10$ に，一方右側のそれが $N=$ 16 に対応している。この結果より, 相対湿度の高い条 件下では明らかに (B) で示したモデルの方が (C).より 実情に近いモデルであると考えられるが, 相対湿度が低 い場合には（B）だけでなく（C)のような状態も存在す ると考えられた. つまり, ハロイサイトの層間水の脱水 は結晶子の外側から内部へと層に垂直な方向に末反応の 層と脱水層とが $\mathrm{X}$ 線的に干涉した状態で混合層構造を形 成しながら進行するといらモデルが最も妥当であると考 えられた。

このようなモデルから考えられる反応速度はすべての 粒子が同じ厚さの一つの結晶子より構成されているよう な理想的な場合を考えると, これは都築・長沢 ${ }^{17)}$ によれ ばゼロ次反応式で表されることになる. そこで定性的で はあるが 重量減少曲線（図 1）より反応速度を算出し た. なお，層間水が完全に脱水した状態（反応率 $\alpha=1$ ) は一応この試料を $300^{\circ} \mathrm{C}, 24$ 時間加熱時の減少量を基準 とした.このようにして算出した $\alpha$ と時間との関係を Avrami-Erofeev の関係式の形で表したのが図 9 であ る.この図中の直線の傾きは $0.2 \sim 0.3$ の範囲の值を示 し，構造モデルより想定されるゼロ次反応式の場合の傾 き 1.24 より明らかに小さい.この理由としては次のよ うに考えられる. 今回取り扱った伊那産八ロイサイトは 電子顕微鏡観察ではほとんどは大きさがほぼ 数千 $\AA$ 程 度の直径の球状の形態を呈している.これに対して先程 から考えていた結晶子はたかだか層の厚みが 100〜160 Å 程度の大きさであり，実際にはこれらの結晶子が多数 集合して 数千 $\AA$ の大きさの 2 次粒子とも考えられる粒 子を形成している. したがってこれらの内部からの脱水 の際の拡散等が反応速度式に大きく影響を与えていると 考えられる. 特に今回検討した脱水条件はゆるやかなも のであったため, この脱水反応本来の反応次数が求めら れなかったものと判断された.

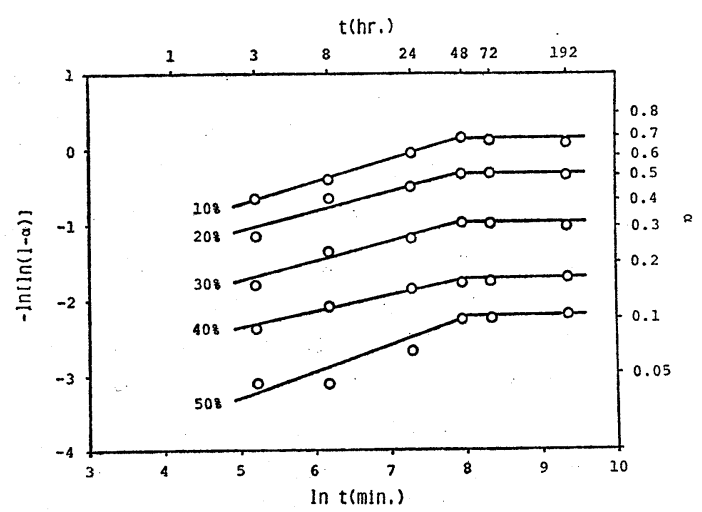

Fig. 9. Plots of $-\ln [\ln (1-\alpha)]$ vs. $\ln t$ of halloysite under various relative humidity conditions. 


\section{4. 総 括}

長野県伊那産のハロイサイトについて室温で相対湿度 を 60〜10\% まで変化させた際の層間水の脱水機構につ いて重量変化の測定と粉末 X線回折法を用いて 検討し た.

まず脱水の際にハロイサイト $10 \AA$ と脱水相のハロイ サイト $7 \AA$ とがX線的に干渉した関倸を保っているか 否かについて検討したところ，(00l).の高次の回折線の 挙動より，両者は干涉した状態を保っていると考えられ る結果であった. 次に Kakinoki ら ${ }^{12)}$ の式を用いてハロ イサイト $10 \AA$ とハロイサイト $7 \AA$ の混合層構造を解 析した結果, ほぼ相対湿度が $30 \%$ 弱の条件でハロイサ イト $10 \AA$ とハロイサイト $7 \AA$ の存在確率が等しくなる こと, つながりの確率は常に $P_{\mathrm{HH}}>P_{\mathrm{HM}}, P_{\mathrm{MM}}>P_{\mathrm{MH}}$ の関係を保っており， segregation の状態で脱水反応が 進行していることなどが判明した.

以上の結果から単純化した種々の脱水モデルについて 検討し, 脱水は一つの結晶子の外側から内部へと層に垂 直な方向に優先的に進行すると考えたモデルが最も観測 結果と調和的であると結論した.

層間水の脱水反応度式についても検討したが，得られ た反応式は前述した脱水モデルより予想されると式と異 なることが判明した.この理由としては, 多数の結晶子 が集まって形成されている球状粒子内部からの拡散等が 大きく影響していると考えられた.

謝 辞 本研究で使用した試料の採取に際して御協力頂い
た服部鉣業（株）伊那鉱業所の南出時二氏に感謝致します．ま た本研究の費用の一部には文部省科学研究補助金 (昭和 56 年度 奨励研究 (A) 56750547) を使用した.

\section{文献}

1）野呂春文, 長沢敬之助, 三鉱学会要旨集 (1981) p. 164 .

2) G.W. Brindley and J. Goodyear, Mineral. Mag. 28, 407-22 (1948).

3) J.L. Harrison and S.S. Greenberg, Clay Clay Mineral., 25, 374-77(1962).

4) K. Nagasawa and S. Miyazaki, Proc. Intern. Clay Conf. 1975, 257-65 (1976).

5) G.J. Churchman and R.M. Carr, Am. Mineral., 57, 914-23 (1972).

6) H. Minato and M. Aoki, Proc. Intern. Clay Conf. 1978, 619-27 (1979).

7) G.J. Churchman, L.P. Aldridge and R.M. Carr, Clay Clay Mineral., 20, 241-46 (1972).

8) D.M.C. MacEwan, A.A. Ruiz and G. Brown. "The X-ray Identification and Crystal Structures of Clay Minerals", Mineral. Soc., London (1961) p. 393-445

9) G. Honjo, N. Kitamura and K. Mihama, Clay Mineral., Bull., 2, 133-41 (1954).

10) F.V. Chukhrov and B.B. Zvyagin, Proc. Intern. Clay Conf. 1966, 1, 11-25 (1966).

11）神山宣彦, 福島球琳男, 媣見 章, 鉱物, 13 (特), 17-26 (1977).

12) J. Kakinoki and Y. Komura, Acta Cryst., 19, 13747 (1965).

13）渡辺晃二, 第四紀研究， 11，295-304 (1972).

14) S.B. Hendricks, Am. Mineral., 23, 295-301 (1938).

15) 佐藤満雄, 粘土科学, 13, 39-47 (1973).

16) M. Sato, Nature, 208, 70-71 (1965).

17）都築芳郎, 長沢敬之助, “粘土科学の進歩 (4)”, 技報堂 (1963) p. 15-22.

実験・技術・調查報告・Report

\title{
溶融 ガラスの電気伝導度測定
}

\author{
若林肇・寺 井良平 \\ （大阪工業技術試験所）
}

誤差の原因となるセル中の不均等電場の形成やセル定数測定に際しての問題点などを避けるため に, 溶融ガラスの電導度測定に適した新しい測定法を開発した. そのセルは, アルミナ又はマグネ シア磁製管に，被測定溶液を満たしたものに，白金の平行平板電極を付けることによって構成され ている. 上部電極には，温度上昇につれて膨張する溶液を逃がすために，白金網を用いている.

このセルを用いてアルカリシリケート及びアルカリ石灰シリケートの幾つかの溶液の電導度を測 定した. この測定による結果と文献值を比較して, その精度と再現性においてかなり優れているこ とが分った. このセルは充分小さくすることができるので, 温度上昇に直ちに追従できる. したが って, この装置は転移温度から液相温度以上の広範囲にわたって, 短時間で連続的に電導度測定が できるという機能性に特徴がある.

(1982 年 12 月 2 日受付) 